\title{
1. Genômica e proteômica
}

\author{
Eloi S. Garcia
}

\section{SciELO Books / SciELO Livros / SciELO Libros}

GARCIA, E.S. Genômica e proteômica. In: Genes: fatos e fantasias [online]. Rio de Janeiro: Editora FIOCRUZ, 2006, pp. 13-49. ISBN: 97865-5708-102-0. https://doi.org/10.7476/9786557081020.0003.

\section{(c) ()

All the contents of this work, except where otherwise noted, is licensed under a Creative Commons Attribution 4.0 International license.

Todo o conteúdo deste trabalho, exceto quando houver ressalva, é publicado sob a licença Creative Commons Atribição 4.0.

Todo el contenido de esta obra, excepto donde se indique lo contrario, está bajo licencia de la licencia Creative Commons Reconocimento 4.0. 


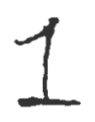

\section{Genômica e Proteômica}

Genômica é o estudo dos genes de um organismo bem como das suas funçōes e interaçōes. A genômica está estimulando a descoberta de novos tratamentos médicos e revelando milhares de novos alvos biológicos (locais de ação de medicamentos) que podem servir para a criação de medicamentos, vacinas e diagnósticos.

Proteômica é um campo emergente que estuda todas as proteínas produzidas pelas células. Este estudo envolve a classificação, caracterização, variaçōes e interações bioquímicas estruturais das proteínas em suas condições normais ou patológicas.

\section{Nem Tudo Está nos Genes}

A pesquisa moderna na genética começou quando Francis Crick com James Watson, após uma caminhada que fizeram até um pub inglês, anunciaram que tinham descoberto 'o segredo da vida'. Desde a descoberta da estrutura do DNA por Watson e Crick, o interesse acadêmico e da indústria biotecnológica pela biologia molecular vem progressivamente aumentando. Nos últimos três anos, esse crescimento se refletiu na mídia, como foi o caso do projeto genoma humano. Após os anos 70, a biologia molecular começou a tomar conta da pesquisa da área biomédica. Tudo tinha de ser compreendido completamente no nível molecular, se possível no nível da genômica. A evolução da enfermidade, sua sintomatologia e consequêencias eram reduzidas ao genoma humano ou do agente infeccioso. Os estudos clínicos, bioquímicos, fisiológicos, imunológicos e patológicos foram perdendo a razão de existir, minimizados pelas investigaçōes dos genes.

As notícias sobre as descobertas da genética molecular, por exemplo, têm levado a sociedade à loucura. Um dia os cientistas encontram genes para asma e para o câncer de pele. No outro dia, são descritos genes de doenças degenerativas nervosas e de síndromes, como a hipertensão, obesidade e depressão. A anemia 
falciforme foi a primeira doença bem definida em termo molecular. Esta doença é causada por uma anomalia na hemoglobina. O problema é devido a uma simples proteína que foi identificada nos anos 40 , seu defeito compreendido nos anos 50 e sua estrutura tridimensional revelada nos anos 60 .

Não resta dúvida de que a genômica, principalmente a comparada e funcional, é fundamental para delinear o mecanismo biológico de uma patologia. A busca é pelo desenvolvimento de um modelo animal que tenha a seqüência genética mais similar à dos seres humanos. $\mathrm{O}$ alvo inicial é realizar modificações genéticas que reflitam na célula ou tecido e o torne sensível, por exemplo, a um hormônio ou a alguma droga que possa reverter a doença no modelo animal utilizado. Se o tratamento funcionar nestes animais, daí entāo, deverá ser testado em seres humanos.

Um dos objetivos almejados pelos pesquisadores é o de criar animais transgênicos que possam desenvolver doenças humanas. Isto facilita a investigaçāo sobre alterações moleculares responsáveis pelas patologias e sobre o efeito de drogas utilizadas na investigação. Distrofias musculares, degeneraçōes nervosas e de órgāos, doenças genéticas que afetam a espécie humana, podem ser investigados em animais de laboratório ou animais domésticos transgênicos. Doenças causadas por mutação genética podem ser graves, normalmente, levando à morte milhares de jovens por deficiências respiratórias, imunológicas ou falhas cardiacas. Várias dessas doenças não têm cura, e os cientistas estão procurando maneiras de inserir nos pacientes os genes responsáveis para bloquear a evolução da doença ou de buscar novos medicamentos para, pelo menos, amenizá-las. Em alguns casos já se consegue inserir genes análogos em camundongos, mas este modelo não reproduz exatamente a doença humana.

Na produção de um animal transgênico vários aspectos científicos necessitam ser analisados com muito cuidado. Por exemplo, estão sendo desenvolvidos animais transgênicos, como a cabra e a vaca, por serem considerados geneticamente próximos aos humanos. Mas a preocupação é de que a modificaçāo genética desses animais possa refletir na qualidade do leite, que é um produto importante em termos nutricionais e de geração de riqueza. É moralmente correto a experimentaçāo em animais como modelos de doenças humanas? É ético usar animais em benefício do ser humano? Não devem ser tolerados experimentos que agridam a ética humana e animal. Se o experimento for um sucesso e, por exemplo, o animal produzir em seu leite uma proteina que beneficie o ser humano com esclerose múltipla, é moralmente correto transformar criaturas vivas em fábricas ou bio-reatores para a indústria farmacêutica humana? 
Este é um ponto complexo porque a maioria dos nossos genes não é exclusivamente do ser humano. Noventa e oito por cento de nossos genes são compartilhados com os chimpanzés, $90 \%$ com os ratos e camundongos, $36 \%$ com os insetos, $23 \%$ com a levedura e $21 \%$ com os vermes. $O$ código genético é essencialmente universal, contendo muitas informações similares em todas as células de diferentes espécies. Ou seja, os genes ultrapassam a barreira das espécies. Por exemplo, a insulina é composta de cerca de 150 aminoácidos, dos quais somente cinco fazem a diferença da insulina humana para a suína. Assim, se a insulina de porco for alterada para insulina humana pela transgênese, o resultado é praticamente o mesmo.

Talvez, para a produção de animais transgênicos, devam ser considerados e reconhecidos os nossos ancestrais mais próximos, que compartilham conosco o maior número de genes. O progresso na compreensão de cada patologia depende do sucesso do trabalho conjunto e multidisciplinar. Para a ciência, as investigaçōes sobre a genômica e da proteômica são da maior importância. No entanto, as promessas exageradas publicadas nos jornais, revistas e programas de rádio e televisão, do que a genômica e o projeto genoma humano podem fazer, não são boas para a ciência biomédica.

Mas, nem tudo está nos genes. Se quisermos que essas áreas sejam benéficas para a população há que se valorizar os bioquímicos, os fisiologistas, os farmacologistas, os imunologistas, os patologistas, os epidemiologistas, os microbiologistas e tantos outros profissionais. Entre os anos 40-60 os cientistas brasileiros estavam trabalhando na bioquímica das frações celulares, células intactas, organismos unicelulares, órgãos de animais e até do próprio homem. Talvez esse período tenha sido considerado 'os anos de ouro' na utilizaçāo do conhecimento gerado pela pesquisa básica e sua aplicação na melhoria da saúde da população.

Não resta dúvida de que a medicina dos anos 60-70 era infinitamente melhor do que a realizada nos anos 30 . Neste periodo as soluções dos problemas vinham de várias maneiras. Por exemplo, os sanitaristas que trabalhavam nos níveis social, cultural, educacional e econômico ficaram responsáveis pelo controle da doença de Chagas. A transmissão da enfermidade pelo vetor em nosso país foi controlada há mais de 25 anos. Os especialistas em cultura de células e tecidos se juntaram aos médicos e aos epidemiologistas e erradicaram a variola e a poliomielite do Brasil. Várias doenças infecciosas foram controladas pela uniāo dos microbiologistas e bioquímicos aos químicos e médicos. 
As infecções ocorriam na natureza devido à existência de bactérias, vírus, fungos ou parasitas, e dependiam da interação molecular entre o germe e o hospedeiro. Desde que Stanley Prusiner descobriu o prion em 1982, a medicina passou a conviver com uma infecção sem um organismo patogênico. Existe um tipo de doença cujo agente infeccioso é uma proteina, sem participação de organismos infectantes. Esta patologia é fatal e apresenta formas diferentes de manifestação nos seres humanos e animais. As partículas protéicas infecciosas são conhecidas como príons, que são proteínas mal formadas capazes de se desenvolverem, replicarem e passarem para células próximas. Além da manifestação da doença, os príons também ocorrem naturalmente em alguns organismos (como a levedura) e podem ter um importante papel no crescimento e desenvolvimento celular.

A descoberta de que proteínas podem transmitir doenças foi uma surpresa para a comunidade científica. O que leva uma seqüência de aminoácidos que induz os príons a se agregar e replicar e assim se perpetuar por geraçōes de células? As proteínas que formam os príons existem normalmente como componentes celulares normais, mas possuem uma habilidade inata para alterar as estruturas tridimensionais de proteínas próximas, as quais mudam suas funções e se tornam quase indestrutiveis. Os prions se propagam por este mecanismo de induzir proteínas normais a modificar suas estruturas terciárias espaciais e se transformarem nestas fortalezas moleculares.

Durante muitos anos acreditava-se na hipótese que o prion era uma única proteína que poderia gerar diferentes tipos moleculares com variados graus de infectividade. Recentes pesquisas estabeleceram que os príons podiam ser decorrentes de estruturas mal formadas de uma mesma proteína. Esta descoberta pôde esclarecer como os prions causam doenças nos seres humanos e animais. Estes dados foram obtidos com prions de levedura, os quais são similares aos príons de mamíferos que causa patologia fatal, destruindo o cérebro humano doença conhecida, em bovinos, como mal de Creutzfeldt-Jacob, encefalopatia espongiforme, mal da vaca louca, e, em ovinos, como scrapie.

Com base nos dados dessas pesquisas foi levantada a hipótese de que os príons transmitem suas características via interação proteína-proteína, na qual um prion com conformação tridimensional anormal influencia sua contrapartida a assumir o enovelamento irregular. Nos mamíferos, a infecção por prions induz proteínas anormais, que formam massas insolúveis, que se aderem na superfície dos neurônios levando a formaçōes esponjosas. 
Os prions afetam diferentes regiōes do cérebro. A morte das células nervosas infectadas dá ao cérebro a aparência de uma esponja, daí o nome genérico da doença, encefalopatia espongiforme. Em células de levedura a proteína príon insolúvel não é letal; ela altera o metabolismo celular. Tanto os príons de mamíferos como os de leveduras adotam conformaçōes infecciosas similares, caracterizadas pelo alto conteúdo de lâminas beta (43\%), com de alfa-hélices (30\%). Estes agregados, conhecidos como amilóides, estão também associados a várias doenças neuro-degenerativas de origem não infecciosa, incluindo Alzheimer e Parkinson.

A produçāo de tipos diferentes de príons pode levar a conformações que infectam espécies diferentes dos animais originalmente infectados. Vários experimentos realizados demonstraram que cepas diferentes de príons de levedura podem transmitir suas características estruturais específicas simplesmente moldando outras proteínas. Estão sendo desenvolvidas técnicas para produzir tipos específicos de proteínas príons de levedura variando a temperatura na qual as proteínas enoveladas são novamente produzidas em suas conformações infectivas.

Em tubos de ensaios os pesquisadores demonstraram que as conformações produzidas nas proteínas, em diferentes temperaturas, propagaram suas estruturas em tipos distintos de príons, provendo moldes em suas formas para o enovelamento de outras proteínas. Estas proteínas de diferentes conformaçōes, quando introduzidas em células de levedura, induziram a produção de diferentes tipos de príons, que passaram suas propriedades moleculares e biológicas a várias gerações destas células. Este fato comprovou a hipótese de que a doença da vaca louca e outras relacionadas são causadas somente por proteínas príons.

Extraindo as proteínas príons de gerações subseqüentes das células, verificouse que tais proteínas tinham as mesmas propriedades da proteína original que infectou a levedura. A habilidade de produzir, manipular e investigar tipos distintos de prions em levedura permitirá estudos mais detalhados de como as proteínas amilóides se formam e propagam. Essas investigaçōes serāo bastante úteis para dirigir futuras pesquisas sobrẹ as propriedades dos prions que causam a doença nos mamíferos e sobre como estas proteínas se infectam em diferentes espécies animais.

Pequenas quantidades de formas diferentes de proteinas prions obtidas de espécies de diferentes mamíferos, quando colocadas em contato com proteínas normais de uma das espécies, podem formar um novo prion, o qual absorve as 
propriedades do prion da espécie fornecedora. Ou seja, esta nova espécie de prion tem a mesma seqüência inicial de aminoácidos, porém adquire a conformação molecular tridimensional e a especificidade do prion que serviu de molde à proteina.

Assim, este príon pode infectar outras espécies de organismos, o que nāo ocorria com a proteína em sua forma original. O fato descrito levanta novas hipóteses para um problema complexo, que é a passagem de uma proteína anormal por diferentes espécies de mamíferos. Este fenômeno também ocorre nos príons de leveduras.

A aparente habilidade de prions diferentes adotarem novas especificidades, contornando as barreiras naturais entre as espécies, tem implicação nos fatores de risco envolvidos na transmissão das doenças de príons animais para os seres humanos. Agora os pesquisadores possuem uma ferramenta de trabalho para explorar o mecanismo molecular pelo qual a proteína espontaneamente muda sua estrutura tridimensional para causar a doença.

\section{Novas informações}

1) Recentemente, os príons foram purificados sendo retirados contaminantes, como micróbios, vírus, bactérias, ou quaisquer agentes que contenham DNA ou RNA. Estas proteínas purificadas foram inoculadas em cérebros de camundongos que posteriormente apresentaram a doença. Foram também sintetizados fragmentos grandes da molécula protéica normal que poderia gerar o príon. Estes fragmentos foram enovelados anormalmente e inoculados em camundongos. Após um ano, estes animais desenvolveram a doença da 'vaca louca'. Os cérebros desses camundongos inoculados em animais normais causaram o aparecimento da doença em seis meses. Isto demonstrou, pela primeira vez, que um fragmento protéico do príon, sintetizado em tubos no laboratório, era suficiente para transformar, nos animais, as proteínas em prions infecciosos.

Este fato representa o renascimento da biologia do príon, pois agora se tem uma ferramenta capaz de explorar, no laboratório, o mecanismo pelo qual a proteína pode-se enovelar espontaneamente para forma espacial que causa a doença. É uma curiosa ironia que este conhecimento tenha sido divulgado na mesma semana que Francis Crick morreu. Este cientista afirmava desde o início que o código genético era universal para todas as formas de vida e formulou o dogma central da biologia molecular que afirmava que a seqüência normal de 
eventos vem do DNA para RNA e deste para proteínas. O dr. Prusiner postulou que para a produçāo de príon não são necessários DNA e RNA.

2) A revista Science, de 11 de novembro de 2004, publicou um artigo que mostra que a variação genética pode causar resistência ao mal da 'vaca louca', levando a uma diferente forma da doença. Esta anomalia ainda não foi encontrada em seres humanos, mas foi observada em camundongos. É sempre muito complicado aplicar os dados de animais de laboratórios para o ser humano. No entanto, são esperadas outras formas da doença. Como já vimos, a doença é conhecida como encefalopatia esponjiforme bovina (BSE) e destrói o cérebro causando um enorme problema quando contamina o ser humano. Esta patologia causou 146 óbitos na Inglaterra e mais de dez mortes em outros países entre 1980 e 1990. A versão humana da doença não é causada pela BSE, mas é causada também por prion e conhecida como variante Creutzfeldt-Jakob (vCJD).

O trabalho da Science mostra, após uma década de investigação, que a injeção de cérebros de camundongos como príons vCJD, conhecidos por alterar as proteínas produzidas pelos genes MM, leva à aparência de esponja do cérebro. No entanto, cérebros deletados dos genes MM também apareciam como esponjas, uma nova forma da doença que agride o cérebro, mas com depósitos de material diferente na extensão e localização se comparados às formas conhecidas da doença vCJD. A proteína envolvida na doença é conhecida como $\operatorname{PrP}, \mathrm{e}$, dependendo de uma diferença genética, pode existir em duas formas no homem: M129 (considerando o aminoácido a metionina) e V129 (a valina). Os camundongos contaminados com a forma humana da doença ( $P r P$ M129) podem apresentar sintomas da vCJD, enquanto que, quando apresentam a forma V129, são resistentes. Quando estes camundongos resistentes tornam-se infectados, aparece uma forma nova da patologia. O fato mais chamativo do artigo é a possibilidade de aparecer uma nova doença causada por príon não associada ao BSE e vCJD.

\section{A 'Finalização' do Projeto Genoma Humano}

Em fevereiro de 2000, Francis Collins e Craig Venter, os dois líderes do Projeto Genoma Humano (PGH), junto ao então Presidente Bill Clinton na Casa Branca, anunciaram a 'finalização' do primeiro rascunho da sequiência genômica. Clinton declarou: "estávamos aprendendo a linguagem pela qual Deus criou a vida". No início de 2004, vinte anos após ter sido lançada a idéia 
do projeto mais ambicioso da pesquisa biomédica c após a revelação de inúmeros aspectos dos genes responsáveis pela vida humana, o PGH foi dado como finalizado.

Em futuro próximo, pretende-se dar continuidade a este desafio com a investigação de genes para a determinação da raça, etnia, comportamento, personalidade e patologias. Outros enfoques genéticos importantes para a condiçāo humana, incluindo planos para amenizar as dificuldades éticas, sociais e legais que envolvem este assunto bem como aspectos médicos, também serão investigados. A seqüência de nucleotídeos do DNA levou a decifrar a intimidade e os mistérios da vida, causando um profundo impacto social. Aprendemos rapidamente como os seres humanos são geneticamente semelhantes ou diferentes um dos outros.

A idéia de elaborar um PGH surgiu em 1984. Um grupo de cientistas, reunidos em Utah nos EUA, debatia sobre as maneiras de identificar as mutaçōes genéticas induzidas nos sobreviventes às bombas atômicas que explodiram em Hiroshima e Nagasaki, durante a Segunda Guerra Mundial. Em 1987, o Departamento de Energia americano, em seus relatórios, já recomendava ao governo realizar um esforço para determinar a seqüência do genoma humano. Não se sabe como, mas esta idéia foi apoiada por alguns setores mais conservadores da sociedade americana. Em 1990, o congresso americano disponibilizou recursos financeiros para a realização do PGH. Os esforços embutidos nos objetivos do PGH foram comparados aos desafios de elaborar a tabela periódica no século $\mathrm{XIX}$, a qual ordenou sistematicamente os cem átomos conhecidos, de modo que fossem detectadas suas similaridades e diferenças.

O projeto tinha como prazo para encerramento o ano de 2005 e o compromisso de tornar todos os dados públicos. Muitos acreditavam que o PGH não poderia ser realizado no período estipulado para a tarefa. A tecnologia necessária para a realização do projeto ainda era precária, fragmentária e quase indisponível. Os primeiros anos foram dedicados principalmente ao desenvolvimento de metodologia para seqüenciar fragmentos de DNA e avançar na parte da biologia computacional, armazenamento e análise das seqüências (bioinformática).

Os genes são compostos de DNA, que é uma molécula formada de 4 bases: adenina (A), timina ( $T$ ), guanina $(G)$ e citosina $(C)$. Cada molécula de DNA consiste em duas fitas, com a base nitrogenada ligada por pontes de hidrogênio a uma base da outra fita, processo conhecido como pareamento das bases (A- 
T e G-C), levando à famosa estrutura da dupla hélice. A tecnologia do seqüenciamento revela as ordens das bases em cada fita que compōe o DNA.

$\mathrm{O}$ PGH envolveu um enorme, estafante, metódico e rotineiro trabalho de laboratório. A determinação da seqüência não poderia ser realizada por um simples grupo de pesquisadores. Assim, a realização da tarefa somente foi possivel com a formação de uma rede de laboratórios, principalmente nos EUA e Europa. Somente nos EUA foram 258 laboratórios, financiados pelo Instituto Nacional de Pesquisa do Genoma Humano (NHGRI), criado em 1989 para administrar o PGH, o qual é parte dos Institutos Nacionais de Saúde (NIH).

Com um custo estimado de USS 2,6 bilhōes, a seqüência do genoma humano forneceu a ordenaçāo de 3,1 bilhōes de letras que compōem o DNA, preenchendo os espaços que ainda faltavam e corrigindo erros observados nos primeiros dados apresentados, em 2000, em cerimônia na Casa Branca.

A seqüiência foi divulgada cinqüenta anos após de James Watson e Francis Crick terem publicado na revista Nature Reviezus Genetics o histórico trabalho da revelaçāo tridimensional da estrutura do DNA. Esta descoberta revelou, pela primeira vez, a conformação do DNA e a base química da hereditariedade. Após a revelaçāo da estrutura do genoma, muitos processos bioquímicos necessitaram ser compreendidos. Por exemplo, como os genes realmente são ativados e inibidos no ato do desenvolvimento e manutenção de um organismo ou do próprio ser humano. Ou seja, como certas regiōes do genoma, que codificam as instruçōes genéticas responsáveis pelo desenvolvimento de um ser vivo, são reguladas.

É difícil desenvolver um programa de computador que identifique os genes ao longo da imensa fita de DNA. Procurar genes no DNA é como tentar localizar uma agulha no palheiro. Genes são como ilhas espalhadas no oceano do genoma. A estimativa final é de que o genoma humano é constituído de cerca de 30 mil genes, bem menos dos 100 mil que se pensava inicialmente. Mas, estes números ainda podem mudar, pois continua a análise em busca de novos genes. A longa fita do DNA é formada de regiōes codificantes (genes), que representam somente $1,5 \%$ do genoma e que controlam a sintese de proteínas no organismo. Mas grande parte do DNA ( $98,5 \%$ do genoma) possui regiões não codificantes que foram conhecidas por vários anos como DNA lixo. Os cientistas estão trabalhando nestes segmentos misteriosos do DNA, que parecem ser essenciais para a sobrevida dos vertebrados, mas cuja função ainda é totalmente desconhecida. 
Tais segmentos são ultraconservados na linha evolutiva e podem ter funçōes nunca imaginadas antes. Em um estudo de genômica comparada, feito $\mathrm{cm}$ uma 'varredura' em duzentas ou mais regiōes do DNA lixo do ser humano, do camundongo e do rato, foram encontrados mais de oitocentas bases que eram absolutamente iguais entre as três espécies. Embora 111 destes elementos ultraconservados coincidam com regiōes de genes conhecidos por codificar proteínas, 256 demonstraram não ter coincidência com genes, e em 114 regiōes os resultados não foram conclusivos. Nas 111 regiōes que coincidiam com os genes, somente uma pequena porção estava em regiōes realmente codificantes. Várias estavam em regiões não que nāo eram traduzidas pelos RNA mensageiros, ou em regiōes que eram deletadas antes da mensagem ser traduzida para proteína. Isto é realmente uma surpresa. A seqüência dos genes que compōem os genomas do camundongo, do rato e do homem, por exemplo, apresenta somente $85 \%$ de similaridade.

Assim, concluímos que cerca de $1 / 4$ das seqüências do DNA lixo coincide com regióes do genoma que sāo codificantes e podem ser convertidas em RNAm - a molécula intermediária que codifica as proteínas. Estas seqüências, geralmente envolvendo um gene que produz diferentes protcínas, podem ser retiradas, ou não, da molécula de RNAs de diferentes formas, dependendo de como sāo transcritas. Um outro grupo de segmentos de DNA lixo nāo está associado com genes, e sim, possivelmente, com a regulação genética, a transcrição do DNA para RNA, ou a ligaçāo com proteínas regulatórias do DNA. Foi descoberto no DNA lixo de leveduras uma nova classe de genes - o gene chamado SRG1 que sintetiza uma molécula de RN $\Lambda$, o qual reprime ou inativa a funçāo do gene adjacente.

Aparentemente, as regiōes conservadas, que não coincidem com os genes, estão envolvidas na regulação da transcrição. Entretanto, se isto é verdade, como elas funcionariam ainda é um mistério. $O$ que os cientistas acham mais interessante sobre estes dados é que eles levantam mais questões do que respostas. Por exemplo, vários elementos conservados nāo vinculados a genes tendem a se agrupar em certos locais dos cromossomos. Estes grupos estão freqüentemente próximos a genes e são conhecidos por terem papéis na regulação de atividade de genes envolvidos no desenvolvimento embrionário. $O$ fato de as regiōes conservadas no processo evolutivo estarem agrupadas espacialmente ao redor dos genes importantes para o desenvolvimento sugere que elas têm algum papel na regulação dos processos do desenvolvimento e diferenciação, ainda que no segmento linear estas regiōes estejam distantes do gene. 
Estas regiōes similares coincidem também com as das aves e cães. Entretanto, estes segmentos foram menos conservados no genoma de um peixe chamado fugu. Quando se estende a comparação para genomas mais antigos, como da Drosophila e do verme, quase não se encontram estes elementos conservados. A conclusão mais interessante é que as regiōes ultraconservadas identificadas parecem representar inovações evolucionárias que podem ter ocorrido em alguma época durante a evolução dos vertebrados. Talvez, as espécies de cordato tenham evoluído quando nossos ancestrais ainda estavam no oceano, quando os animais iniciaram a colonização do solo. Após este período, os segmentos gênicos foram mantidos congelados nas aves e nos mamíferos.

Uma nova visão sugere que muito dos códigos contidos no DNA são para síntese de RNAs especiais, não codificantes de proteinas, os quais agem com moléculas reguladoras. Estes RNAs podem agir ligando-se a RNAs mensageiros, tornando-os inativos, e também podem funcionar como reguladores da atividade gênica. Assim, a grande parte da estrutura do DNA é para produzir estes RNAs regulatórios não codificantes de proteínas. Olhando para além dos genomas, estes segmentos do DNA lixo do homem, camundongo e rato possuem $97 \%$ de similaridades e $95 \%$ deles são semelhantes aos das aves. O fato de estes segmentos terem sofrido poucas mudanças nos 400 milhões de anos de evolução em que o peixe e o ser humano dividiram um ancestral comum mostra que estes segmentos do DNA lixo são essenciais para os descendentes destes organismos.

Recentemente, os pesquisadores descobriram que é ativada a expressão de genes em óvulos fertilizados de mamíferos nos estágios iniciais de desenvolvimento embrionário $\mathrm{cm}$ parte por regiōes do DNA que podem ter origem de retrovírus. Estas regiões, encontradas em DNA humano, do camundongo e de outros mamíferos em centenas de cópias, são chamadas de retrotransposons devido ao fato de terem a habilidade de se propagarem e inserirem em posições diferentes do genoma. Estas regiōes parecem não serem apenas DNA lixo, elas podem ser sítios repositórios para iniciar a expressão gênica. Assim, regiões do DNA antes consideradas nāo funcionais podem ter um papel importante na regulaçāo da expressão e na promoção da diversidade genética. Tais elementos podem sincronicamente iniciar a expressão de genes múltiplos relacionados ao desenvolvimento do embrião e, devido à inserção randômica de tais regiōes, podem introduzir variaçōes potenciais em genes modificando suas funçōes. A expressão de retrotransposons pode contribuir para a reprogramação do genoma embrionário dos mamíferos, um pré-requisito para o desenvolvimento normal. 
Os erros no genoma podem ser encontrados pelo computador, e talvez corrigidos por ele. Se isto for verdade, o conceito de um gene como uma simples seqüência de segmento do DNA está se evaporando. No início do PGH, a identificaçāo de um simples par de bases, ou letra do código genético, custava cerca de US\$10, e um técnico altamente especializado poderia seqüenciar 10 mil pares de bases por dia. Hoje, com o avanço tecnológico na área, o custo da identificação de um par de bases é de 5 cents, e os equipamentos robóticos chegam a seqüenciar 10 mil pares de bases por segundo. Em 2000, a freqüuencia de erros encontrada na seqüência do DNA era de 1 para cada 10 mil bases, agora é de 1 para 100 mil, e a distância ao longo da seqüência onde poderia ter uma falha era de 82 mil bases; agora é de 27 milhões de bases.

No entanto, embora o PGH esteja formalmente 'finalizado', a seqüência do genoma ainda não está completada. Aproximadamente $1 \%$ do genoma não pode ainda ser seqüenciado pelas metodologias existentes. Deverão ser desenvolvidas novas tecnologias para completar esta tarefa. O atual desafio está sendo a compreensão da biologia molecular básica através da interpretação da vasta informação contida na molécula de DNA. Um grupo de 152 pesquisadores está conseguindo novos detalhes e desenvolvendo um catálogo mais compreensivo dos genes humanos. Para isto, está sendo caracterizado o genoma nāo somente pela sua seqüência, mas também pela sua função e diversidade. $\mathrm{O}$ genoma humano possui aproximadamente 30.000 genes em um organismo que deve produzir mais de $200 \mathrm{mil}$ proteínas diferentes. Isto sugere que existe um mecanismo complexo e interdependente de regulação genética, demonstrando a complexidade da rede genômica e proteômica que diferencia os seres humanos entre si e dos organismos inferiores.

Especialistas em análise do genoma humano, utilizando-se de uma combinação de algoritmos computacionais, processaram 41.118 DNA complementares (cDNAs). Desde que os éxons (regiōes do DNA) foram separados e os introns removidos, estes cDNAs correspondem às versões funcionais destes genes. A comparação destas seqüências do cDNAs com as do genoma levou a validar 21.037 genes funcionais e identificar 5.155 candidatos novos a genes.

O conceito de gene, entretanto, é ainda nebuloso. Uma única seqüência pode ser usada de maneira diferente para sintetizar RNAs e proteínas. Se um gene pode ser expresso em maneira e locais diversos e em tempos variados, não é possível dizer que ele é um único gene. Este é um problema novo a ser 
resolvido. A análise de gene por todos estes métodos tem mostrado seqüências complexas. Por exemplo, parece que as seqüências genéticas tendem ser mais longas no início e no final dos genes que nas regiōes do meio. Ainda nāo há uma explicaçāo para isto. Fragmentos de DNA, às vezes compreendendo milhares de nucleotídeos, estão presentes ou ausentes em genomas de pessoas saudáveis.

As informações do PGH indicaram que o DNA era $99,9 \%$ idêntico entre os indivíduos, apresentando somente $0,1 \%$ de variação, geralmente distribuída por todos os cromossomos. Novos dados, entretanto, revelam que, em 255 regiões do genoma (mais de $0,1 \%$ ), grandes fragmentos do DNA estāo presentes em cópias diferentes entre os indivíduos. Estes estudos mostraram que, por exemplo, algumas pessoas têm 10 cópias do gene da amilase e outras podem apresentar mais de 24 cópias.

A genômica tem tido um profundo impacto nos estudos dos microorganismos e das doenças. Quando os biologistas discutem sobre a revoluçāo genética, prometem o desenvolvimento de novos medicamentos para patologias incuráveis, novos revolucionários tratamentos e uma mudança expressiva nos cuidados médicos. É difícil imaginar o que seria da ciência na ausência da genômica. Desde que o primeiro genoma de uma bactéria patogênica foi divulgado em 1995, mais de 100 bactérias patogênicas e mais de mil vírus foram seqüenciados.

Por todo o planeta há sinais de impaciência e desilusão sobre o que o genoma pode oferecer. Parece que houve um exagero por parte dos líderes do projeto criando uma percepção pública de que o DNA seria a resposta para todos os mistérios biológicos. Por outro lado, especulações financeiras lançaram a idéia de que este conhecimento teria aplicações imediatas. Ledo engano, todos envolvidos no PGH sabiam que não seria assim, ou seja, conheciam o script, mas nāo entendiam a linguagem.

Vários cientistas argumentam que, após quatro anos da revelação do genoma humano, ainda não houve um progresso real no tratamento dos principais males que afetam a humanidade: pobreza, Aids, malária e outras doenças infecciosas. Outros acreditam que houve um gasto de bilhões de dólares no desenvolvimento do PGH, em detrimento de uma pesquisa mais holística. Por exemplo, se gasta milhões de dólares na pesquisa do genoma do plasmódio (protozoário causador da malária) e do mosquito transmissor desta doença, quando não há recursos financeiros na África para utilizar um método simples de prevenir a transmissāo da malária. É difícil rejeitar completamente estes argumentos. 
Apesar do dilema levantado pelas novas descobertas genômicas, ainda é muito cedo para uma reação contrária ao estudo de genomas. Vivemos um período maravilhoso da ciência de nossa época, da descoberta da estrutura de DNA à decodificação genoma humano. Afinal de contas, o DNA contém o nosso passado, pode definir o nosso presente e ser o início de nosso futuro.

$$
\text { Genoma humano - um projeto concluído? }
$$

A revista Nature Reviews Genetics publicou a seqüência 'final' do genoma humano no dia 21 de outubro de 2004. Algumas pessoas ficaram confusas com esta notícia. Antes já tínhamos visto por duas vezes esta divulgação. A primeira em uma cerimônia na Casa Branca em fevereiro de 2000, quando o primeiro rascunho do DNA humano foi completado, e a segunda em abril de 2003, quando o Consórcio anunciou a 'finalização' do PGH.

A surpresa neste artigo foi a redução do número de genes humanos contidos nos cromossomos: de 35 mil genes para somente 20 a 23 mil genes. A seqüencia apresentada representa $99 \%$ da região eucromática (que contém genes) e foi seqüenciada com uma eficiência de $99,999 \%$, o que significa a possibilidade de um erro em cem mil pares de base - 10 vezes mais acurada de que no objetivo original. Desta maneira foi confirmada a existência de 19.599 genes e 2.188 segmentos de DNA 'prováveis' de codificarem proteínas. A média de bases do DNA seqüenciada ininterruptamente equivale a 38,5 milhões de pares de base, isto é, aproximadamente 475 vezes mais longa do que os 81.500 pares descritos anteriormente.

Além da redução do número de genes, os pesquisadores reportaram que a melhor qualidade da seqüência do genoma humano, comparada com os primeiros dados divulgados, permitiu observar uma imagem mais realista de certas regiões como, por exemplo, a duplicação de segmentos do DNA e do surgimento e desaparecimento de certas atividades gênicas. Os segmentos duplicados são extensos, quase cópias idênticas do DNA, apresentando pelo menos duas localizações no genoma. Esta alta proporção de segmentos duplicados demonstra que nosso material genético, nos últimos 40 milhões de anos, sofreu inovações funcionais e estruturais, contribuindo para a separação do ser humano dos outros ancestrais primatas.

A alta qualidade da seqüência do genoma humano revelada no artigo permitiu aos cientistas detectarem mais de mil novos genes que apareceram após nossa divergência dos roedores, processo que ocorreu há cerca de 75 milhōes de 
anos. Muitos desses genes apresentaram duplicaçōes recentes na história do homem e estão envolvidos com a imunidade, o olfato e a reprodução.

Foram também identificados e caracterizados 33 genes - conhecidos como pseudogenes -, que sofreram uma ou mais mutaçōes, conduzindo a perdas funcionais. Por exemplo, dez desses pseudogenes têm função de codificar proteínas envolvidas no olfato. Isto pode explicar por que os seres humanos têm um número menor de receptores olfativos e, conseqüentemente, apresentam a recepção do cheiro menor do que os roedores. Estes estudos deram o prêmio Nobel de fisiologia e medicina a Richard Axel e Linda Buck, em 2004.

Os pesquisadores também alinharam e compararam os 33 pseudogenes com o rascunho do genoma do chimpanzé para investigar se estas seqüências eram ainda funcionais antes de o Homo sapiens divergir dos macacos há cinco milhōes de anos. Esta análise revelou que 27 dos pseudogenes não eram funcionais no homem e no chimpanzé. Entretanto, cinco genes não ativos nos seres humanos eram ativos no primata, o que explica a vantagem olfativa do chipanzé em relaçāo ao homem.

Quando se fala que a seqüência do DNA humano está 'finalizada' não significa que se tem a seqüência perfeita do genoma. Em 2000, por ocasião do primeiro anúncio do rascunho do genoma humano, havia 150 mil regiōes desconhecidas. Agora somente permanecem 341 brechas no DNA que necessitam novas tecnologias para serem desvendadas. Assim, esta publicaçāo da Nature Reviews Genetics ainda não é o final da história. Há algumas regiōes do genoma humano que não podem ser elucidadas pelos métodos utilizados até agora. Nos próximos cinco anos poderão aparecer novas histórias sobre a 'finalização' do DNA humano.

\section{- Retorno das Zoonoses}

O mundo está ficando pequeno para seus habitantes. Em busca de novas áreas para plantio ou exploração, o ser humano devasta florestas, drena pântanos, constrói estradas e represas, invade regiōes e florestas virgens à procura de riquezas. As viagens internacionais estão ficando cada vez mais freqüentes e mais ousadas. Qualquer região deste planeta, antes inexplorada e inexplorável, pode ser atingida por uma pessoa em 24 horas. A locomoção de um indivíduo permite que ele tenha contato, por exemplo, com um vírus na África ou no Brasil e, no outro dia, esta pessoa poderá estar caminhando nas ruas de Nova Iorque, Londres, Paris ou Rio de Janeiro. 
Os cientistas estão extremamente preocupados. As mudanças causadas no planeta, principalmente aquelas relacionadas ao desenvolvimento cconômico, estāo alterando o ecossistema, aumentando a possibilidade de novos agentes patogênicos se propagarem e causarem riscos à saúde humana e animal. Ou seja, as mudanças ecológicas estão influenciando na epidemiologia das zoonoses, podendo ser de origem natural ou antropogênica, quando considerada a economia. Estas alteraçōes incluem, mas não estão limitadas, a expansão da população humana, o reflorestamento e outras trocas no habitat, poluiçāo ou mudanças climáticas. Um exemplo mais global do que isto representa é o caso de vírus da Aids. Inicialmente, devido ao desenvolvimento da rede viária no interior do continente, o vírus infectou caçadores que tiveram acesso às florestas tropicais da África. A doença se propagou pelo contato humano e tornou-se uma tragédia global devido à relativa facilidade das pessoas viajarem pelo planeta.

Novas doenças aparecem ou emergem, como a gripe espanhola, que se espalhou pelo planeta em 1919, matando de 30 a 50 milhōes de pessoas. Esta doença tirou mais vidas do que a primeira guerra mundial. A gripe asiática, de 1957 , levou quase 100.000 vidas, e a de Hong Kong matou aproximadamente 50.000 indivíduos, em 1968.

Uma nova epidemia é esperada. Não se sabe se ela virá de forma natural ou mesmo por um ataque terrorista. Uma nova ameaça para a humanidade poderá ocorrer por um novo micróbio ou por uma mutação de um microorganismo já conhecido. Não resta dúvida que os agentes patogênicos continuam evoluindo. Novos micróbios têm sido descobertos e merecem uma atençāo permanente das autoridades responsáveis pela saúde pública, pois poderāo causar epidemias.

Dos novos microorganismos identificados podemos citar o hantavírus, responsável pela síndrome pulmonar, o ébola, os vírus Lasso e Marburg que são agentes causadores da febre hemorrágica, o vírus Nipa da encefalite, o microorganismo causador da doença dos legionários e a cepa de Escherichia coli, responsável por uma diarréia sanguinolenta e alterações renais. Vários casos já apareceram nos noticiários rotineiros da mídia como prováveis infecções zoonóticas ainda sem explicações científicas convincentes.

Embora várias doenças sejam transmitidas entre a mesma espécie (espécieespecífica, ou seja, aquelas enfermidades que podem ocorrer em uma única espécie animal), outras tantas podem se propagar entre diferentes espécies. São consideradas zoonoses, as doenças de animais que passam ao ser humano, ou seja, a passagem de agentes infecciosos entre os animais, domésticos ou selvagens, e o homem. Algumas zoonoses são bem conhecidas, como a praga, a doença de 
Lime, a raiva, a influenza, várias verminoses e doenças parasitárias de cães, gatos e outros. Em 2001 foram catalogadas 1.415 agentes patogênicos para o ser humano, $62 \%$ destes tinham origem nas zoonoses.

Especialistas acreditam que há risco de novas viroses animais contaminarem o ser humano. Trinta e cinco doenças zoonóticas já foram descritas nos últimos 25 anos. Dezenas de doenças graves, transmitidas por animais, serão descobertas nos próximos 50 anos. A maioria delas será detectada na América Central e do Sul, África e Ásia.

A passagem de micróbios dos animais para o ser humano é conhecida desde os tempos remotos. Há milhares de anos, quando os primeiros pequenos aglomerados humanos se formaram e os animais começaram a ser domesticados, iniciaram-se as permutas de germes entre os animais e o homem. Há dois mil anos o ser humano começou a viver em grandes cidades e esta situação piorou.

É importante saber mais sobre a interface existente entre o homem e animais e como e por que certos microorganismos ultrapassam as barreiras das diferentes espécies animais e passam ao ser humano. Certas zoonoses causam doenças devastadoras. Um exemplo marcante de zoonose é o próprio vírus HIV, que está causando a pior pandemia desde a peste no século XIV. Originado de macacos selvagens, passou ao ser humano em poucas décadas, causando a Aids. Em contrapartida, acredita-se que o coronavírus responsável pela Síndrome Respiratória Aguda Grave (Sars) contaminou ao homem através de gatos selvagens asiáticos. Recentemente, uma nova gripe asiática, possivelmente, transmitida por aves, causou várias mortes no Vietnã e quase se transformou em uma pandemia.

Doenças como a Sars, HIV e a gripe asiática, provavelmente tornaram-se infecções zoonóticas por uma razão básica do processo evolutivo dos organismos. $\mathrm{Na}$ realidade, todos que pensam ecologicamente não ficaram surpresos com o aparecimento dessas doenças. Estas viroses estão tentando se evoluir. Por exemplo, os cientistas acreditam que as pandemias mortais de influenza tiveram início na Ásia e foram transmitidas por animais. Possivelmente a cepa virulenta do vírus se desenvolveu onde porcos e aves são criados juntos, em locais próximos a fazendas. Os suínos foram infectados pelo vírus de pato, e este vírus, ao recontaminar os porcos, infectou os seres humanos, criando epidemias desastrosas para o planeta.

Um dos grandes problemas das epidemias humanas é que um vírus que circula entre animais, sofrendo uma mutação, pode tornar-se um agente agressivo 
às pessoas. Como isto pode ocorrer? É um risco sério? Por exemplo, uma cepa de influenza A tem circulado pelo mundo há dezenas de anos. Este microorganismo normalmente se propaga somente entre as aves, causando, por vezes, uma patologia menos grave e, em outras vezes, uma doença grave, levando a uma grande incidência de mortalidade entre estes animais.

O vírus é essencialmente um parasita que penetra numa célula e utiliza a sua maquinaria metabólica e reprodutiva para se dividir (replicar). Para sobreviver com sucesso, este organismo deve se adaptar à célula infectada. Muitos vírus não sofrem mutaçōes facilmente. $\mathrm{O}$ vírus $\mathrm{H} 5 \mathrm{~N} 1$ da influenza aviária, como o HIV, notoriamente é uma exceção. $\mathrm{O}$ microorganismo da influenza possui um alto índice de mutaçāo, o que significa que é muito flexivel e pode se adaptar a novos ambientes. Este vírus pode sofrer mutação de duas maneiras: uma de mudanças mais lentas, com reflexo pequeno na saúde pública, pois o indivíduo contaminado tem tempo para desenvolver resistência produzindo anticorpos. $\mathrm{E}$ a outra, de transformaçōes genéticas rápidas, que podem originar novas epidemias.

A maior transformação genética ocorre quando um tipo de vírus animal permuta genes com um virus relacionado. Desta maneira, o novo vírus pode ganhar características que não tinha antes, tornando-se competente e mais virulento ou contagioso ao homem. Este é o caso do H5N1 que pode fundirse com um virus comum da gripe humana, talvez em alguém que tenha influenza, ou com um vírus de um animal, como o porco, o qual pode estar contaminado pelo vírus da gripe humana e aviária. Assim, um novo vírus letal e contagioso pode surgir. Dados recentes demonstraram que este vírus coletado em 2002 é muito mais infeccioso para frangos e camundongos do que o vírus isolado em 1997. Isto pode indicar pequenas mudanças genéticas no H5N1. No entanto, o virus $\mathrm{H} 5 \mathrm{~N} 1$ possui quatro obstáculos genéticos e ambientais que dificultam a sua contaminação na população humana. $O$ primeiro é que a replicação viral em células humanas não é muito eficiente. Ou seja, somente uma pequena concentração do vírus pode ser espalhada pela tosse ou espirro. $O$ segundo obstáculo é que o vírus aviário é incapaz de infectar eficientemente células humanas. Aparentemente, o receptor celular de certos tipos de células humanas não é muito adequado ao vírus. A terceira dificuldade é que o vírus aviário é encontrado no tubo digestivo das aves, onde a temperatura é em torno de $37^{\circ} \mathrm{C}$. No trato respiratório humano a temperatura é de cerca de $33-34{ }^{\circ} \mathrm{C}$. Esta diferença de temperatura pode prejudicar a replicação virótica. O último 
obstáculo é que as viroses aviárias estāo bem adaptadas e escapam do sistema imune das aves. Entretanto, nāo conseguem fugir do sistema de defesa humano.

Aparentemente, o vírus $\mathrm{H} 7 \mathrm{~N} 3$, que ataca maciçamente os frangos, não entrou ainda em contato com nenhum material genético humano. Esse vírus não é normalmente letal, mas alguma coisa acontece com ele, que passa a ser altamente patogênico. O H7N3 é diferente da cepa $\mathrm{H} 5$ que matou várias pessoas bem como milhares de frangos na Ásia. O H e $\mathrm{N}$ representam diferentes proteínas. Existem 15 variedades de $\mathrm{H}$ e 9 de $\mathrm{N}$. As proteínas se combinam de diferentes modos para fazer as viroses específicas, algumas mais mortais que outras.

Recentemente foram revelados detalhes de como o vírus da gripe espanhola, originada de uma gripe aviária, se transformou na epidemia mais destrutiva da história. Devido ao fato de o vírus manter as caracteristicas básicas de seu precursor aviário, ele pode escapar do sistema imune, causando uma alta disseminação entre indivíduos e uma mortalidade extraordinária. Baseando-se em amostras isoladas de vítimas preservadas e enterradas em regiões cobertas permanentemente de gelo no Alaska, os cientistas reconstruíram partes do genoma do vírus extinto. Regiōes do genoma reconstruído foram usadas para produçāo de proteínas do vírus, principalmente uma glicoproteína (hemaglutinina) de membrana conhecida com HA.

Esta molécula tem um papel crucial nos primeiros estágios da infecçāo virótica, em que o vírus se adere nas células humanas e sofre o primeiro ataque pelo sistema imune. O HA do vírus da gripe de 1918 é similar aos vírus de origem aviária. Isto explica a razão desta pandemia ter sido tão letal. A proteína HA pode ser reconstruída em forma tridimensional após sua cristalização e após a determinação da estrutura ter sido estudada em raios-X. Esta molécula foi comparada com a do virus da gripe aviária atual, cepa A (H5N1) e foi demonstrado que elas não são semelhantes e se aderem em células humanas de modos diferentes.

Baseando-se nos dados da epidemia de 1997 em Hong Kong, estas variações explicaram porque o $\mathrm{H} 5 \mathrm{~N} 1$ se espalha pelos seres humanos de modo limitado, em contraste com o vírus de 1918 que tem a habilidade de ser propagado rapidamente. $\mathrm{O}$ vírus $\mathrm{H} 5 \mathrm{~N} 1$ necessitaria de mais mutaçōes para transformar em infectante e contaminar de pessoa a pessoa. Em parte, a grande mortalidade de 1918 foi devida a complicaçōes das infecções secundárias causada por bactérias. Hoje, estas seriam tratadas com antibióticos, de modo que uma epidemia similar àquela seria mais difícil. 
Os pesquisadores acreditam que a evolução dos microorganismos seja a razão de doenças animais passarem aos seres humanos, sendo este processo de ocorrência mais freqüente no futuro. Recentes trabalhos científicos têm demonstrado que as migraçōes de aves, de significado nostálgico às pessoas, pode ser a causa principal da transmissão de virus. Não temos a capacidade de evitar as catástrofes naturais nem as epidemias. Quanto mais mudar a ecologia humana, mais estaremos criando oportunidades para os micróbios e doenças evoluírem e se espalharem pelo planeta. A vigilância sanitária humana e animal deve estar sempre em estado de alerta.

Pela sua natureza, a saúde pública é multidisciplinar, devido à utilização de vários determinantes sociais e econômicos, bem como por ter um enorme espectro de ações de promoção e prevenção da saúde. Assim, causou-nos surpresa a mídia ficar interessada na Sars somente dois anos após começar a surgir conseqüências da epidemia que ocorreu de 2002 a 2003. Em 2003, ocorreram 8.098 casos de Sars, em 29, países causando 774 mortes. Os sistemas de saúde desses países, que deviam estar preparados para enfrentar doenças emergentes e reemergentes, cometeram equívocos primários ao enfrentarem a epidemia. Por exemplo, através do contato com pacientes infectados com Sars, as autoridades de Toronto identificaram 23.103 pessoas que ficaram em quarentena, ou seja, cerca de $1 \%$ da população da cidade. Em Taiwan 211.045 , indivíduos suspeitos de terem contato com pessoas doentes foram isolados entre 10-14 dias. Felizmente, somente 133 destas pessoas foram contaminadas. Situaçōes semelhantes foram observadas em outros países onde a Sars ocorreu. Esta foi a principal lição desta epidemia. Os países devem organizar seus sistemas de saúde para enfrentar epidemias imprevistas ou novas que, de alguma maneira, possam colocar a população em risco.

\section{Sobre a Gripe Aviaria}

Em novembro de 2004, a Organização Mundial da Saúde (OMS) divulgou que, após quase um ano tentando controlar, na Ásia, a gripe aviária, esta é candidata a causar, nos próximos anos, uma pandemia, com possibilidade de provocar cerca de três milhões de casos fatais. $O$ vírus responsável pela doença não somente é resistente, mas também extremamente versátil. $O$ vírus da gripe das aves, H5N1, que causou mais de 30 óbitos humanos na Tailândia e Vietnã além de milhares de mortes de frangos em toda a Ásia, em 2004, é certamente o agente patogênico mais provável para causar a próxima pandemia. Historicamente, as pandemias de influenza aparecem a cada 20 a 30 anos, 
quando ocorrem mudanças no vírus, e a população tem pouca ou nenhuma imunidade para este agente com novo perfil genético.

A OMS acredita que o vírus aviário possa combinar-se ao vírus da gripe humana, criando uma nova forma que pode se espalhar rapidamente pelo planeta, estimando cerca de dois a sete milhões de mortes e bilhōes de pessoas contaminadas.

A vacina para proteger os seres humanos deste vírus deverá estar sendo produzida em 2007, após extensos testes clínicos. Pesquisadores tailandeses isolaram o vírus de cinco casos humanos e enviaram amostras para o Centro de Controle de Doenças nos Estados Unidos. Tais amostras virais estão sendo usadas para desenvolver vacinas contra a doença. A primeira vacina será testada no início de 2005, e os pesquisadores acreditam que em três anos será desenvolvida uma vacina eficiente e segura para proteger a população.

Genômica, Proteômica e saúde

O relatório do Foro Global para Pesquisa em Saúde nos mostra que a maior parte dos recursos financeiros liberados vai para pesquisa de doenças, como a influenza, hepatite, doenças cardiovasculares, diabete, entre outras que afetam problemas globais, principalmente do Primeiro Mundo. Por outro lado, ainda são insuficientes os recursos para pesquisa contra malária, Chagas, Aids, tuberculose, esquistossomose, leishmaniose, filariose, das quais várias predominam ou são problemas exclusivos dos países em desenvolvimento ou menos desenvolvidos. Por isto, estas doenças são consideradas doenças negligenciadas. Entre 1975 e 1999, de aproximadamente 1.200 medicamentos novos existentes no mercado, somente 13 eram para tratar doenças tropicais.

A OMS reuniu-se em Genebra no mês de maio de 2004, em sessāo plenária com todos os 192 países associados. Uma das decisões tomadas pela assembléia foi de como o setor saúde se beneficiará pela enorme revolução ocorrida na genômica e proteômica, células-tronco e transplantes. As investigaçōes foram facilitadas com a divulgação da seqüência do genoma humano bem como de muitos agentes patogênicos (incluindo a malária, cólera, doenças diarréicas, tuberculose, Aids e hanseníase) e de agentes vetores de doenças (como o mosquito Anofeles e o verme Esquistossomo).

O genoma é a seqüência completa do DNA de um organismo. Possuindo um tamanho variável dependendo do organismo considerado, representa a 
unidade de hereditariedade. O menor genoma conhecido é o das bactérias que contém cerca de 600 mil pares de bases, enquanto o genoma humano e de camundongo possuem aproximadamente 2,9 bilhōes. Entre os objetivos do PGH estava a identificação de aproximadamente 30 mil genes e as seqüências dos pares de base, além de tornar os dados acessiveis gratuitamente para pesquisas. O PGH é uma extraordinária fonte de informação sobre o desenvolvimento científico da bioquímica, fisiologia e evoluçāo das espécies existentes no planeta.

O DNA carrega os códigos para síntese das proteínas. Entretanto, até 1960 , ainda era totalmente desconhecido, assim como as informaçōes contidas no DNA eram utilizadas para produzir as proteínas. Sidney Brenner e François Jacob, quando trabalharam na Califórnia, identificaram o RNA mensageiro (RNAm), molécula que transportava as informações contidas no código genético do DNA ao ribossomo, local da síntese de proteínas. O RNAm é produzido no núcleo celular de maneira complementar ao gene contido no DNA e serve como molde para a síntese de proteínas ao ligar-se aos ribossomos, nos quais, através um processo complexo, o código é então traduzido na seqüência de aminoácidos que forma uma proteína particular.

O proteoma representa o conjunto das proteinas que compōe um organismo vivo. Este tema de investigação pretende catalogar e caracterizar as proteínas derivadas do código genético, comparar as variaçōes dos níveis de expressão em diferentes condições, estudar suas interações e identificar suas funçōes na célula. A natureza e a estrutura das proteínas contribuem para a dificuldade da proteômica, fazendo com que ela seja um desafio maior do que da genômica. Por exemplo, as proteinas têm 20 moléculas (aminoácidos) como componentes básicos, enquanto o DNA é composto de somente quatro substâncias (nucleotídeos).

Além disso, a estrutura da proteína pode se modificar. Uma simples proteína pode ser expressa e se estruturar de maneira diferente dependendo do local de síntese em um organismo ou de seu estágio de desenvolvimento. Trabalhar com proteínas é muito mais difícil do que com ácidos nucléicos. As proteínas nāo podem ser amplificadas e são mais raras de serem encontradas. De mais a mais, as proteínas freqüentemente desnaturam durante os experimentos, o que leva a pequenas ou grandes mudanças estruturais em nível terciário e quaternário.

A genômica e a proteômica causaram modificações dramáticas na química dos ácidos nucléicos e das proteínas e no uso de vários sistemas biológicos. A implementação de processos eficientes para culturas de células, regeneração 
de tecidos e fertilização in vitro de animais pode ser realizada devido à disponibilidade de protocolos estabelecidos para utilização das ferramentas moleculares (enzimas de restriçāo, sistemas vetores de DNA, elementos transposomais, promotores, marcadores genéticos, genes clonados etc) pela inserção precisa e rápida de genes úteis em plantas, animais e microorganismos.

Calcula-se que o ser humano, entre proteínas funcionais (enzimas, hormônios, etc) e estruturais (componentes de membranas, organelas, etc), possua de quatro a seis vezes mais proteínas do que o número de genes. A teoria de que um gene codifica uma proteína, como se ensinava na universidade, já saiu dos livros modernos de bioquímica.

O PGH passou quase despercebido pelos laboratórios brasileiros, mas o país acabou investindo bastante em rede genômica de microorganismos e parasitas e, mais recentemente, na rede para investigação da proteômica. A comunidade científica brasileira pôde assim participar ativamente na produção e na interpretação dos dados de genomas e proteomas de diferentes organismos. As informações contidas nas seqüências de DNA, no entanto, não revelam suas funçōes celulares. A transformação dessas seqüências em informações úteis é uma tarefa científica enorme.

A maioria dos medicamentos desenvolvidos tem como alvo a ação funcional e/ou estrutural das proteínas. Estima-se que qualquer proteína codificada por um único gene possa ter inúmeros tipos de variaçōes, que podem ser produzidas de diferentes maneiras: erros resultantes de mutação genética e modificaçōes pós-transcrição e pós-tradução, por exemplo. As vias metabólicas nas quais moléculas de RNAs e proteínas agem e interagem podem elucidar as bases genéticas das doenças humanas e seus tratamentos. As oportunidades e desafios na utilização dessas informações fornecem novos conhecimentos que podem ser convertidos em inovaçōes significantes em termos comerciais.

Cada vez mais aparecem evidências de que a compreensão da genômica e proteômica dos microorganismos e seus vetores facilita a prevenção e o tratamento da doença. Um desses casos foi a divulgação do genoma de três organismos envolvidos em uma enfermidade: o parasita, o mosquito e o ser humano. Este é o caso da malária em que o plasmódio possui cerca de 5.300 genes distribuídos em 24 milhões de pares de base química do DNA; o mosquito, aproximadamente 14.000 genes em 278 milhões de pares de base.

Talvez, a melhor maneira de olhar uma doença é considerarmos os fatores ambientais e genéticos. Enquanto o debate continua, muitas empresas estāo 
investigando a relação entre gene e doença. Numa perspectiva genética, as doenças são causadas quando um gene que devia estar inativo torna-se ativo, ou vice-versa. De qualquer maneira, não resta dúvida de que vários aspectos da saúde ou da doença humana são definidos pelo DNA. Conhecendo a seqüência genética do hospedeiro e do microorganismo causador da patologia, será possível estudar os vários genes envolvidos, as proteínas codificadas por estes genes e como estas moléculas atuam numa patologia. Este enfoque explicará os mecanismos das doenças, de como os microorganismos patogênicos driblam o sistema imune e afetam as funçōes básicas de nosso organismo. Tais informações poderão gerar diagnósticos mais sensiveis e específicos, medicamentos com menores reações colaterais e novas vacinas. Os testes genéticos serão usados para diagnosticar, dar informações do prognóstico, evolução ou estimar o risco de uma doença futura em indivíduos saudáveis ou em suas proles. Por exemplo, mutaçōes no gene PIK3CA são encontradas em diversos tipos de câncer. Este gene e outros de sua família fornecem as instruções genéticas para a síntese de enzimas chamadas de lipídeo-quinases, que modificam moléculas de gorduras. Estes dados abrem oportunidades para o desenvolvimento de terapias específicas que podem ser úteis para tratamento de câncer com mutaçāo neste gene.

Um outro exemplo é a esperança de cura para a diabete tipo 1 . Normalmente, esta doença ocorre devido a uma combinação entre o ambiente e fatores genéticos. No entanto, pessoas que não possuem o gene Sumo-4, que regula o sistema imunológico, também possuem diabete tipo 1 por destruiçāo das células produtoras de insulina no pâncreas. Foi demonstrado, por outro lado, que célulastronco humanas ativam certos genes que têm uma funçāo importante no pâncreas. Os genes da insulina e glucagon normalmente ativados nas ilhotas pancreáticas também foram ativados em células-tronco. O próximo passo será recriar nas células-tronco as condições que produzem insulina e glucagon em resposta ao nível de glicose no sangue.

O conhecimento sobre os genes envolvidos em uma doença e a via metabólica ou o local de ação de um medicamento leva à descoberta de centenas de novas possibilidades de alvos para uma droga. Utilizando-se desta estratégia, medicamentos também têm sido testados em vários tipos de câncer, lúpus, hepatite $\mathrm{C}$, deficiência de hormônio do crescimento, úlceras venosas crônicas, imunodeficiências, doenças cardiovasculares e osteoporoses, entre outras.

Além dos exemplos anteriores, pelo uso da genômica e proteômica, podese produzir insulina humana em animais para tratamento da diabete, ativador de plasminogênio para dissolver coágulos sangüíneos, fator VIII utilizado nos 
hemofílicos para formação do coágulo, ou estreptoquinase e uroquinase na dissolução do mesmo, fatores de crescimento. Estas tecnologias também são utilizadas para controle da poluição ambiental pelo tratamento de lixos e poluidores, como o petróleo, DDT, dioxina, $\mathrm{PCBs}$ e outros químicos que envenenam a natureza com microorganismos (bactéria e fungo) engenheirados.

As investigaçōes sistemáticas e compreensivas da genômica e proteômica de diferentes microrganismos, animais e vegetais levarāo a novos enfoques para entender a biologia nos próximos anos. No Brasil já existe uma massa crítica altamente especializada em ciências biológicas e nas tecnologias da informática aplicada à biologia. É preciso estimular a interação de grupos que trabalham em genômica e proteômica com os que estāo criando ferramentas para acelerar o desenvolvimento de novas drogas. No entanto, ainda há vários senōes quanto ao uso da genômica e proteômica na área de saúde. Nos anos recentes, o desenvolvimento da medicina parece depender quase que exclusivamente da genômica médica. A idéia de produzir novos medicamentos utilizando o conhecimento da genética das pessoas para identificar prematuramente doenças de alto risco para intervir no início ou mesmo antes de a doença aparecer é uma promessa. Esta seria a medicina do futuro, a qual identificaria indivíduos cujo genes aumentariam a susceptibilidade a certas doenças.

Apesar de esta promessa ser amplamente divulgada é ainda precipitado assumir que a genômica médica se tornará rapidamente uma realidade. $O$ conhecimento sobre genes e doenças ainda é muito pequeno para predizer o risco de um paciente desenvolver ou nāo uma doença. Durante algumas décadas, a pesquisa médica identificou 1.500 doenças (chamadas mendelianas), nas quais uma mutaçāo em um único gene prediz o risco de uma pessoa desenvolver a doença.

No entanto, a maioria das doenças é dependente de mais de um gene, ou seja, é poligênica, e isto complica em muito a utilização da genômica na área médica. É verdade que pessoas portadoras dos genes BRCA1 e BRCA2 têm riscos de desenvolver câncer de mama, e aquelas com o gene FAP podem ter câncer colo-retal. Mas estes representam somente a minoria dos casos de câncer.

O nosso mercado farmacêutico, estimado em mais de US $\$ 12$ bilhões/ano, é um grande competidor no mercado mundial. Uma das áreas importantes para o processo de inovação de fármacos é a bioinformática (a integração da biologia, ciência da computação e tecnologia da informação). Os avanços significativos dependem da área de aplicação e integração com bases de dados, simulação, 
modelagem molecular, desenho de novas drogas, entre outras. A bioinformática é fundamental para o desenvolvimento das indústrias de medicamentos e vacinas por diminuir significativamente o custo da inovação de um produto.

A rede brasileira de laboratórios vinculados à genômica e proteômica está distribuida por todo o país. $\mathrm{O}$ mercado mundial com vistas ao desenvolvimento de novos medicamentos pelo uso da bioinformática é de US\$25 bilhões, crescendo a uma base de $15 \%$ ao ano. Em um planeta onde se patenteia tudo, apesar do custo proibitivo da descoberta e desenvolvimento de um novo medicamento, uma droga nova no mercado rende muito mais. A genômica e a proteômica sāo bases da fundação de uma nova pesquisa biomédica voltada à indústria farmacêutica. $\mathrm{O}$ Brasil, possuindo a maior diversidade biológica do planeta e uma comunidade científica competente, pode realmente fazer a diferença nesta nova era se houver estímulo e cooperação público/privado fértil e eficiente.

\section{Notícias sobre o fumo}

Em um estudo conduzido pela doutora Jacqueline Vink da Holanda e publicado no Pharmacogenomics Journal, foi sugerido que o grau de dependência à nicotina e, até mesmo, o número de cigarros que é fumado por dia por uma pessoa, são influenciados geneticamente. Utilizando-se de gêmeos não idênticos, os pesquisadores encontraram quatro marcadores genéticos que parecem estar associados ao vício do fumo. Eles se localizavam nos cromossomos 3, 6, 10 e 14 , sugerindo que pelo menos quatro genes estāo envolvidos neste processo. $\bigcirc$ resultado obtido especialmente no cromossomo 6 revelou que o marcador genético identificava um conjunto de genes de um tipo conhecido como alfa glutationa S-transferase. Estes genes carregam as instruçōes para sintese de enzimas que desintoxicam vários agentes químicos tóxicos, incluindo alguns conhecidos como causadores de câncer. Tais genes são mais ativos nos pulmões e no intestino. Pessoas com deficiência nestes genes demoram a metabolizar a nicotina, aumentando o prazer causado pela droga. É possível, com base neste artigo, que se possa classificar as pessoas que fumam socialmente e aqueles que sāo viciados fisicamente em nicotina.

Em minha opinião, esses resultados devem ser interpretados com muito cuidado, como em todo artigo que relaciona os genes a comportamentos, pois a repetição de tais estudos em populações com valores culturais e morais diferentes é sempre de difícil comprovação. 


\section{A Seqüência das Proteinas e o Proteasoma}

Há alguns anos atrás, imaginava-se que a seqüência dos genes no genoma humano refletia automaticamente, nos produtos funcionais dos genes, a seqüência dos aminoácidos nas moléculas de proteínas, e assim poder-se-ia desvendar os mecanismos responsáveis pela biologia celular e processos patológicos. Entretanto, este cenário nos livros didáticos está se modificando rapidamente.

Recentemente, foi descrito um processo celular inédito que levanta algumas dúvidas sobre o paradigma: a seqüência de uma proteína está baseada na seqüência do seu gene. Por exemplo, quando uma enzima é necessária para que se processe uma etapa do metabolismo celular, segmentos de uma região específica do DNA, chamados éxons, são transcritos em moléculas de RNA. Este é traduzido na seqüência dos aminoácidos que forma a estrutura da proteina enzimática. Quando esta enzima nāo é mais necessária para o metabolismo celular, é degradada por um complexo enzimático conhecido com o nome de proteasoma. Ou seja, numa definição mais ampla, proteasomas são enzimas, encontradas no núcleo e no citoplasma celular, que degradam proteinas que têm a vida curta, bem como proteínas anormais e defeituosas obtidas por erros de tradução ou transcrição, ou mesmo por deficiência gênica. Conseqüentemente, os proteasomas, participando da destruição destas proteínas, influenciam na regulação do ciclo celular.

O que se sabia, anteriormente, era que proteínas com diferenças funcionais podiam ser produzidas por pequenas modificações, como a incorporação de pequenas moléculas aos aminoácidos, quebra ou falha na seqüência protéica, ou omissão de certas regiões do gene alterando a tradução do RNA mensageiro. Entretanto, hoje se sabe que a seqüência de uma proteína pode ser modificada pelo proteasoma. Esta descoberta leva a um novo processamento da proteina e é uma novidade para a função do proteasoma.

A modificação pós-tradução foi descoberta após a análise de seqüências de peptídeos que ativam o sistema imunológico em resposta à presença de células cancerígenas. Estes peptideos antígenos são formados quando os proteasomas fragmentam proteínas específicas em peptídeos e os transportam para a superfície celular, marcando-a para ser destruída pelas reações imunes.

A destruição ou modificação das proteínas demonstrou como um processo celular realmente importante guarda um equilibrio complexo entre as formas úteis e as que vêm a ser dizimadas. A ubiquitina é uma das moléculas que se encarrega de marcar as proteínas que devem ser destruídas. Este processo é 
chamado por alguns pesquisadores como o 'beijo da morte', devido ao fato de as células 'ubiquinadas' serem imediatamente destruidas no proteasoma.

O grupo de pesquisadores que estudou este processo encontrou um antígeno peptídico, com uma seqüência totalmente diferente da seqüência de seu gene, que estimulava o sistema imune a reconhecer e destruir células de melanoma. $O$ mecanismo de ação também ficou esclarecido. $O$ proteasoma age sobre uma proteína recém-sintetizada quebrando-a em três peptídeos. Posteriormente, estes peptídeos são reagrupados de maneira que a proteína antígeno passe a ser reconhecida pelo sistema imune após perder parte de sua sequiência original.

Este processo de modificação pós-tradução é realmente fantástico e pode ter implicações no planejamento de vacinas baseadas $\mathrm{em}$ peptídeos sintéticos, contra a Aids, câncer e outras patologias. Os peptídeos utilizados nas vacinaçōes, por exemplo, podem sofrer modificaçōes estruturais pela ação dos proteosomas, complicando o monitoramento, nos pacientes, das respostas imunológicas a vacinas. Esta descoberta é intrigante pela complicaçāo adicional na identificação do peptídeo antígeno. Até se saber quando, por que e qual é a frequêencia deste processo ocorrer, nāo se pode garantir que o genoma humano responda a todas as questōes relacionadas às seqüências das proteínas sintetizadas pela célula.

\section{Watson e crick}

James Watson e Francis Crick, os pais da biologia molecular, trabalharam no modelo da estrutura de dubla hélice do DNA, na Universidade de Cambridge, e divulgaram a descoberta em um modesto artigo de uma página da revista Nature Reviews Genetics, em 1953. Basicamente, os dois cientistas descreveram a estrutura de dupla hélice e mostraram como os dois segmentos que formam a hélice do DNA se separam,cada um servindo de molde para formar a outra metade, quando a célula se divide. Pela primeira vez, ficava demonstrado que o DNA podia se reproduzir sem mudar sua estrutura.

Pouco anos depois, Watson mudou-se para Cambridge nos EUA, onde, em 1956, tornou-se professor da Universidade de Harvard. Com sua entrada, concomitantemente chegava também a biologia molecular na Harvard, uma disciplina ainda incipiente naquela época. A biologia molecular teve um crescimento explosivo e um avanço extraordinário nos últimos 50 anos. Naquele tempo ela tinha um enfoque reducionista, fracionando os organismos vivos em pequenas estruturas celulares e/ou moleculares. 
Apesar da revolução biológica iniciada em 1953, os cientistas não acreditavam que a biologia molecular fosse suficiente para esclarecer alguns dos processos importantes do que conhecemos como vida. O sucesso da revolução reducionista estava na idéia de que o processo que acontecia em nível molecular forneceria dados para interpretar o mais geral, ou seja, refletiria a atividade celular. Cinqüenta anos após a descoberta da estrutura do DNA e o fortalecimento da biologia molecular, uma nova visão mais integrada para compreender as células, que conhecemos como sistema biológico, está ganhando espaço na ciência. A atenção atual está direcionada, por exemplo, na exploração da complexidade com que as redes de proteínas celulares interagem entre si e com outras moléculas, e não simplesmente na beleza estrutural da dupla hélice.

$\mathrm{O}$ encerramento do $\mathrm{PGH}$, no início de 2004 , revelou a seqüência fria e cansativa das bases de nucleotídeos $\mathrm{A}, \mathrm{C}, \mathrm{T}$ e $\mathrm{C}$ que compõem a longa fita do DNA. A maioria dos segmentos contidos nesta estrutura ainda é completamente misteriosa e obscura para a ciência. Agora, a tarefa para os pesquisadores é estudar como as seqüências dessas bases são agrupadas para constituírem genes ativos, e como estes genes são regulados para produzir proteínas e manter um organismo vivo. Não há possibilidade de saber o que está ocorrendo em uma célula se nāo se entenderem as interaçōes entre seus componentes. Ou seja, somente uma visão ampla e irrestrita dos sistemas biológicos nos mostrará como funciona a biologia celular.

O DNA, que contém as instruções genéticas necessárias para fazer um homem ou qualquer outra forma de vida, é uma molécula longa que está muito compactada no núcleo da célula. Várias regiōes do DNA constantemente são desempacotadas e expandidas, como as dobras do fole de um acordeão, em resposta às necessidades celulares. Quando a molécula do DNA relaxa ou expande, proteínas, chamadas fatores de transcrição, têm acesso ao código genético para ler as instruçōes responsáveis pela síntese de RNA mensageiros, os quais servem de moldes para síntese de proteínas. Quando o DNA está enovelado e compactado, como o fole de um acordeão fechado, os genes não estão acessíveis para as proteínas de transcrição.

Sabe-se que a célula humana coordena, de maneira extremamente eficiente e precisa, a atividade de seus 30.000 genes. Cada uma de nossas células contém a molécula de DNA medindo um total de dois metros, enovelada dentro do núcleo celular, que possui um diâmetro de somente 1/100 de um milímetro. Isto é comparável a empacotar $20 \mathrm{Km}$ de um fio finíssimo de arame dentro de uma bola de tênis. Este enovelamento é importante na ativação e inativação dos 
genes e decide como a célula se comporta, tornando-se uma célula da pele, uma célula hepática ou um neurônio, ou se a célula é saudável ou doente. Sem o desenvolvimento de tecnologias sofisticadas seria impossivel investigar os sistemas biológicos, pois estes envolvem centenas de processos que ocorrem simultaneamente na célula.

Várias técnicas estão sendo utilizadas para analisar o grau de expansão ou compactação do DNA. Geralmente estas técnicas se baseiam em chips de RNA. Entretanto, somente uma pequena fração de genes induz uma síntese de RNA suficiente para ser detectado pelos chips. Recentemente, foi desenvolvida a técnica do chips de cromatina, que dá um detalhe maior de quais genes estão propensos as ativaçōes ou inibiçōes. Com esta técnica, se comparada aos chips de RNA, pode-se conseguir maior informação sobre o número de genes e saber se eles estão ou não induzindo a sintese de RNA. Assim, esta técnica pode nos indicar nāo somente se um dado gene do DNA está presente ou nāo, mas também o grau de compactação ou extensāo do DNA.

A compreensão de como o genoma controla as funçōes celulares nāo diminuiu a importância do enfoque reducionista usado com sucesso por tantos cientistas e por tanto tempo. Por exemplo, os pesquisadores estão aprendendo mais sobre uma proteína chamada condensina, que tem uma importância vital para compactar a molécula de DNA e manter sua integridade estrutural. Assim, a longa fita de DNA mantém seus constituintes compactados através de um complexo especial de condensina, até o período da divisão celular. Os cientistas observaram como o DNA é compactado pelo complexo de proteínas por meio de microscópios magnéticos e vídeos. Assim, observou-se, por exemplo, como o material genético dos organismos vivos se duplica para criar outras gerações de células. A técnica é relativamente simples: moléculas individuais de DNA são fixadas, por uma de suas extremidades, a uma lâmina de vidro, e, pelo outro lado, a uma superfície magnética. Pequenos magnetos distendem e contraem as moléculas. Uma força variável e controlada distende a molécula de DNA, possibilitando avaliar as mudanças na compactação, seguida das interações com o complexo da condensina.

Com base neste teste foi revelado que este complexo de condensina, quando submetido a forças fracas, compacta o DNA. Ao aumentar as forças magnéticas, este processo é revertido, ocorrendo a distensāo da estrutura do DNA. Um outro método excelente para entender a complexidade das redes biológicas é a técnica de microarray para DNA, descoberta na década de 1990, e que permite 
que os cientistas determinem, em uma única vez, os níveis relativos dos genes expressos nas células.

As células rearranjam dramaticamente seus genomas para permitir que os genes sejam expressos. Como mover os móveis em uma casa para arrumar mais espaço, a mudança cromossomal extensiva é acompanhada por estruturas móveis de empacotamento do DNA. Estas estruturas - conhecidas como nucleossomas - são complexos de proteínas presentes em diferentes pontos do genoma. Sabe-se agora que o nucleossoma marca território. Os genes para serem expressos de modo mais eficiente perdem seus nucleossomas que, entretanto, retornam quando os genes são inibidos.

A focalização de um simples gene não permite perceber os processos que estão ocorrendo na célula em um dado momento. É necessário estudar a genômica de um organismo, pois ela significa algo mais integrado para compreender o que está ocorrendo na célula. A genômica é uma ciência altamente comparativa. A tecnologia dos chips pode ajudar no diagnóstico de defeitos genéticos que causam doenças. Células obtidas de um tecido canceroso e um tecido saudável podem ser comparadas e analisadas, dando idéia do que levou o câncer a se desenvolver.

Esta técnica pode também ajudar no entendimento e tratamento de doenças. Os medicamentos podem ter efeitos diferentes em indivíduos que possuem pequenas modificações genéticas. Mas, encontrando o tipo de gene de uma pessoa, pode-se escolher o medicamento e a dose ser determinada para um máximo da efetividade (farmacogenômica). Tais avanços, entretanto, necessitam de novos conhecimentos de como as proteinas interagem na célula. Nos próximos 15 anos, quando um paciente for ao médico, levará o mapa de seu DNA seqüenciado por somente algumas centenas de reais.

\section{Algumas considerações importantes}

O prêmio Nobel Francis Crick faleceu nos EUA, no dia 28 de julho de 2004, aos 88 anos.

Após 13 anos de trabalho, um novo, e talvez o último, relatório do consórcio internacional de laboratórios que decodificaram o genoma humano, publicado na Nature Reviews Genetics, de 21 de outubro de 2004, mostra que o ser humano possui um genoma menor do que se estimava. O consórcio, ao divulgar a seqüência do genoma em 2000, falhou em 147.821 regiões do DNA nos 23 pares de cromossomos humanos. Isto não significa que a seqüência anunciada 
agora seja perfeita. Faltando somente 341 regiōes, cerca de 20.000 genes humanos foram identificados e 5.000 mais necessitam serem revelados. Coincidentemente no mesmo número da revista foi publicado que um peixe biologicamente importante possuía também de 20.000 a 25.000 genes. Vamos também lembrar que um dos modelos favoritos para pesquisa, o verme $C$. elegans, possui 19.500 genes e a planta mostarda, Arabidopsis, tem cerca de 27.000 genes. Aparentemente, em comparação com organismos mais simples, o ser humano se beneficia mais dos genes que ativam a produçāo de proteínas múltiplas do que dos genes que codificam somente uma proteína. Assim, muito da complexidade biológica está baseada na seleçāo de diferentes combinaçōes de proteínas e não em uma simples estrutura seqüencial de aminoácidos.

Em 11 de novembro de 2004, o jornal eletrônico PLOS Biology divulgou um artigo mostrando que regiōes não-gênicas do DNA estavam associadas com o desenvolvimento dos vertebrados. Neste trabalho, foi demonstrado que o genoma humano contém inúmeras regiões do DNA que são regulatórias, o que, aliás, está estimado nos métodos computacional e funcional. As análises da seqüência comparativa de regiões do genoma de diferentes organismos podem identificar similaridades e diferenças no DNA. Em geral, as similaridades na seqüência entre organismos divergentes relacionam-se com as atividades funcionais. Neste artigo, os autores comparam o genoma humano com o de peixe, Fugus rubripes, para identificar aproximadamente 1.400 seqüências altamente conservadas em regiōes não-codificantes do DNA. Respeitando a divergência evolucionária entre as duas espécies, conclui-se que estas sequuências sāo essenciais a todos os vertebrados. Além disso, tais seqüências estão localizadas pertos de regiões que agem como reguladoras do desenvolvimento. Algumas destas seqüências são mais de $90 \%$ idênticas. Apesar disto, não se pode encontrar similaridade nos genomas dos invertebrados.

\section{Investimento e Desenvolvimento de Fármacos}

O governo brasileiro definiu o desenvolvimento de fármacos como uma de suas prioridades para a ciência e tecnologia. Não resta dúvida de que as descobertas de novas drogas e o domínio da tecnologia de produçāo e inovação de medicamentos são pontos importantes para a política de saúde de um país. A população deve ter acesso aos novos medicamentos, que estão cada vez mais caros e de difícil aquisição. No desenvolvimento de medicamentos, a primeira instância de ação deve ser o estímulo à busca de drogas para combater as 
grandes endemias e as doenças degenerativas, vasculares e crônicas que afetam principalmente a terceira idade. A segunda prioridade refere-se a medicamentos de alto valor agregado, como fármacos sofisticados e de última geração e drogas cuja ação depende do perfil genético do paciente.

A inovação de um medicamento é um excelente negócio para a indústria. No entanto, o processo de descoberta de um novo fármaco é lento e depende de grandes investimentos em pesquisa. As grandes empresas investem de US $\$ 600$ a US $\$ 800$ milhões - duas vezes mais que uma década atrás - para colocar um novo medicamento na prateleira de uma farmácia. Este é quase o valor utilizado pela Nasa para colocar um homem na Lua. Estes valores são decorrentes de investimentos, realizados pelas indústrias, de mais de US\$30 bilhōes/ano em pesquisa e desenvolvimento na busca de um novo produto - cerca de 15 vezes mais do que era gasto há 20 anos. Apesar disto, em 2001, foram introduzidos 24 novos medicamentos - metade do número de 1996 . Somente 17 novas drogas foram comercializadas em 2003. Este foi o menor número desde 1983. Algumas grandes empresas há mais de dez anos não conseguem produzir novos fármacos.

Normalmente os medicamentos não são efetivos em $100 \%$ da população, e alguns trabalhos revelam que agem somente em $50 / 60 \%$ dos casos. Nos demais casos, os pacientes não respondem ou os remédios provocam sérios efeitos colaterais. Muitos medicamentos prescritos pelos médicos não agem nos pacientes devido às pequenas diferenças nos perfis genéticos (microgenéticas) entre os indivíduos. A recente revelação da seqüência do genoma humano facilitou a soluçāo da questão genética e abriu uma nova área comercial para os próximos anos, a farmacogenômica, cujo mantra é: fármacos certos, nas doses certas, para os pacientes certos. Ou seja, a farmacogenômica epidemiológica passa por várias especialidades médicas, da genética a estudos estatísticos de doenças e controle, e considera como fatores genéticos influenciam a resposta de uma pessoa a uma droga. Isto é visto como um modo de realizar tratamentos mais seguros e efetivos para cada pessoa individualmente. Apesar de esta área estar ainda no primeiro estágio de desenvolvimento, o seu potencial para melhorar o tratamento de pacientes é enorme e, mais importante, a farmacogenômica pode salvar vidas.

Um belo exemplo foi o experimento realizado com uma droga que reduz os níveis de colesterol no sangue. O DNA de 1.536 pessoas foi analisado para a verificação de 148 snps (polimorfismo que ocorre em um único nucleotídeo) em 10 genes candidatos que agem no metabolismo de lipídios. As variações nestes genes foram examinadas pelas mudanças nos níveis de lipídios ocorridas 
durante 24 semanas de tratamento com a pravastatina. Foi descoberto que indivíduos heterozigotos (que carregavam dois alelos diferentes de um gene), para uma variação genética no gene $\mathrm{HMG}-\mathrm{CoA}$ redutase (enzima alvo da droga), tiveram reduçōes menores de colesterol quando tratados com pravastatina. Este dado é interessante por fornecer uma forte evidência clinica para a 'medicina personalizada' e o uso de genômica para certas terapias.

A maioria dos medicamentos tem ação em proteínas encontradas em diferentes compartimentos e estruturas celulares. Por exemplo, o princípio ativo de um remédio pode interagir com enzimas - substâncias que catalisam as reações bioquímicas - ou com proteínas encontradas nas membranas, que são $30 \%$ de todas as proteínas do organismo. Laboratórios dispendiosos que utilizam cristalografia ou imagens de ressonância nuclear magnética são utilizados para conhecer a estrutura tridimensional da proteína-alvo de uma droga. Conhecendo a proteína, para descobrir um novo medicamento, é necessário desenhar potenciais fármacos adequados à estrutura da molécula-alvo, além de desenvolver sistemas para expressar essa proteina, medir a cinética da reação e incorporaçāo, conhecer a termodinâmica do processo, a estabilidade do complexo fármacoproteína alvo e os possiveis efeitos indesejáveis dos fármacos. Nāo é fácil investigar um novo medicamento antes de ser testado nos animais e nos seres humanos.

Recentemente uma nova técnica conhecida como RNA de interferência (RNAi) permite a inserção nas células de RNAi para inibir a ação de um gene escolhido. O RNAi é um fenômeno que tem evoluido rapidamente com técnica poderosa para silenciar a expressão gênica em células eucarióticas. De imediato, essa técnica foi vista como poderosa para tratamento de doenças, como o câncer, diabetes e outras patologias. Os cientistas descobriram que, na célula, moléculas pequenas de RNA se ligam a moléculas maiores responsáveis pela síntese de proteínas. Em experimentos com C. elegans, os pesquisadores mostraram que as moléculas de RNA sintetizadas no laboratório podiam unir-se a RNAs interferindo no componente funcional desta molécula, daí nasceu o nome RNAi.

Estima-se que $30 \%$ de todas as doenças genéticas humanas envolvem erros nos RNAs. Assim, inúmeras patologias que se relacionam com defeitos nos genes ou mesmo descontroles genéticos poderiam ser silenciadas através o RNAi. A diversidade de sua aplicação faz do RNAi uma ferramenta essencial para pesquisadores envolvidos na caracterização da função de um determinado gene, na análise de uma via importante para ação de um medicamento ou mesmo na validação de alvos terapêuticos. $\mathrm{O}$ uso desta tecnologia gera inúmeras oportunidades e desafios. 
Não resta dúvida de que o potencial desta tecnologia no campo da genômica funcional e na descoberta de novos medicamentos é promissor. Por exemplo, o RNAi pode suprimir genes que causam tumores diminuindo o desenvolvimento de câncer. Entretanto, várias barreiras necessitam ser ultrapassadas para utilização desta técnica para pesquisa e aplicação clínica.

As moléculas de RNAi nāo funcionam em bactérias utilizadas normalmente em experimentos. Também elas não podem ser aplicadas sem interferir nas células, e os genes não permanecem suprimidos por longo tempo. Para contornar esses problemas, pesquisadores estão mudando a composição química das moléculas convencionais de RNA usadas no RNAi e combinando a fita simples de RNA com a fita simples complementar do DNA para criar pequenas moléculas híbridas de RNA-DNA.

Estes híbridos são mais estáveis que os RNAi, passivamente penetram nas células por um mecanismo ainda não conhecido e permanecem intactos no interior das células. Assim, as moléculas híbridas de RNA-DNA são mais eficientes que os RNAi, seus efeitos demoram 10 vezes mais dos que os gerados pelas moléculas convencionais, são mais baratas para serem produzidas e são ativas em bactérias e vírus. As moléculas híbridas podem localizar um dano ou uma pequena alteração em um gene, entre seis bilhōes de nucleotídeos contidos em uma única célula, e torná-lo silencioso. É bom lembrar que os genes agem no organismo através da expressão de proteínas e enzimas específicas que cada gene codifica. $O$ código genético contido na seqüência de DNA é transcrito para RNA e finalmente traduzido em polipeptídios - proteínas, enzimas ou hormônios peptídicos. Uma doença genética é resultante de uma mudança no(s) gene(s), gerando produtos genéticos anormais.

O gene inibido pelo RNAi não produz a proteína pela supressão de sua expressão. Esta estratégia de intervenção não está limitada à inibição de genes endógenos - aqueles que ocorrem naturalmente na célula. Ela pode ser também usada para silenciar genes estranhos, tais como aqueles de um vírus ou uma bactéria invasora, assim protegendo o organismo de uma infecção.

Em resumo, para utilizar moléculas híbridas de RNA-DNA, deve-se inicialmente identificar a seqüência de nucleotídeos no gene-alvo. Então, uma pequena seqüência de cerca de 20 nucleotídeos é sintetizada para identificar a sequêencia genética a ser silenciada. Quando esta molécula híbrida for inserida em uma célula, ela se liga seletivamente no RNAm da seqüência-alvo, bloqueando sua capacidade de expressar o produto. A experiência mostra que 
moléculas híbridas, tendo como alvos genes que causam câncer, inibiram o crescimento rápido das células cancerígenas e não causaram efeito deletério nas células normais próximas ao câncer.

A indústria de biotecnologia, tão criticada por cientistas conservadores, movimenta algo em torno de US\$30 bilhões/ano, produzindo mais de 160 medicamentos e vacinas, e possui cerca de 370 drogas e imunobiológicos em vários estádios de testes. A prioridade no desenvolvimento de fármacos depende de uma política industrial forte e agressiva e de grandes investimentos em pesquisa básica e aplicada e de reconhecer que países que negligenciam a produção própria de medicamentos amargam uma perene condição de dependência tecnológica. Há que se investir para fazer a diferença.

\section{RNAi: sobre a descoberta da nova técnica}

A descoberta de RNAi foi em 1998 quando os cientistas revelaram que pequenas fitas duplas de RNA podiam efetivamente se ligar a genes específicos. Logo se imaginou o potencial revolucionário dessa técnica no tratamento de inúmeras doenças. A chamada terapia por RNAi é considerada uma das descobertas mais importantes nos últimos tempos para a ciência biológica devido ao seu poder de silenciar genes indesejáveis relacionados a doenças deixando os demais genes intactos. No entanto, se os RNAis forem dissolvidos no sangue, por exemplo, eles não conseguem penetrar nas células. Mas esta terapia será útil para a medicina se for administrada pelos métodos da medicina convencional.

Dados publicados na segunda semana de novembro de 2004 pela revista Nature Reviews Genetics demonstraram que a técnica de RNAi silenciava o gene responsável pela síntese de apolipotroteína $\mathrm{B}$, diminuindo sua concentraçāo no sangue aproximadamente em $70 \%$ e, conseqüentemente, reduzia a mais da metade os níveis de colesterol no sangue de camundongos. O RNAi ligava-se a proteínas do sangue, o que aumentava sua estabilidade por 15 vezes.

A idéia é que a população de moléculas lipofílicas, como a de colesterol, agiria como cavalo de Tróia para colocar RNAi no interior das células. Os pesquisadores ligaram RNAis a moléculas de colesterol que rapidamente são absorvidas pela célula. Ironicamente, a molécula de colesterol carreava um RNAi para silenciar um gene responsável pelo alto nível de colesterol no sangue. As moléculas de colesterol-RNAi reduziram $37 \%$ o nível de colesterol em camundongos. 
Este é mais um passo em direçāo ao uso clínico de RNAi. A beleza desse resultado está em sua simplicidade. No entanto, ainda sāo necessárias várias experiências para monitorar as aplicaçōes diretas e sistêmicas de RNAi em doenças, como as cardiovasculares, diabetes, obesidade, hepatite, câncer e outras patologias, e para verificar os potenciais efeitos colaterais, quanto tempo o efeito da droga persiste sem a necessidade de inoculaçōes adicionais, ou seja, revelar a eficiência da terapia por RNAi. 